\title{
Geochemistry of late Mesozoic mafic magmatism in west Shandong Province, eastern China: Characterizing the lost lithospheric mantle beneath the North China Block
}

\author{
FEng Guo,* WeIMING FAN, YueJun WANG and Ge LiN \\ Guangzhou Institute of Geochemistry, Chinese Academy of Sciences, Wushan, Guangzhou 510640, P.R. China
}

(Received October 2, 2001; Accepted July 25, 2002)

\begin{abstract}
The mantle lithosphere beneath the North China Block (NCB) was significantly thinned during the last 400 million years. Comparative studies of early Paleozoic and Cenozoic lithospheric mantle have shown that the lost lithospheric mantle should be of similar character to an Archean enriched mantle reservoir, but this hypothesis has been difficult to test due to the absence of basalt-born mantle xenoliths from the late Paleozoic to Mesozoic. Late Mesozoic (early Cretaceous) mafic intrusive and volcanic rocks occurring in west Shandong Province within the NCB are characterized by large ion lithophile element (LILE), light rare earth element (LREE) enrichment and high filed strength element (HFSE) depletion (Nb, Zr, Hf and Ti) as well as EM1-like Sr-Nd isotopic ratios (initial ${ }^{87} \mathrm{Sr} /{ }^{86} \mathrm{Sr}(\mathrm{i})=0.7040$ to 0.7055 and $\varepsilon_{\mathrm{Nd}}(\mathrm{i})=-18.9$ to -9.2 ), that originated from an aged and enriched lithospheric mantle. The inferred Mesozoic subcontinental lithospheric mantle (SCLM) mainly comprised chemically refractory peridotites with disseminated phlogopite, completely different from that present in Cenozoic time. The Mesozoic SCLM was geochemically and isotopically different compared with the early Paleozoic kimberlite-born peridotite xenoliths that contain high modal proportions of phlogopite. These older xenoliths have no or insignificant HFSE anomalies but EM2-like isotopic features that might represent the lowermost part of Archean lithosphere. The widespread occurrence of EM1-like Sr-Nd isotopic characteristics in basaltic magmas of west Shandong Province during the late Mesozoic indicates that the most of the Archean lithospheric mantle was progressively removed through thermal-mechanical erosion by a hot convective mantle, and further modified by subsequent partial melting processes in response to extensional tectonics.
\end{abstract}

\section{INTRODUCTION}

The nature of the SCLM is of great importance for understanding Earth's evolution and basalt petrogenesis. It is widely accepted that certain kinds of mantle reservoirs correspond to the regional tectonic environments (e.g., Hart, 1988; Menzies, 1989; Boyd, 1989). For instance, beneath cratonic regions such as in the Kapavaal, Siberia, Wyoming and Slave Cratons (Pearson et al., 1995; Walker et al., 1989; Carlson and Irving, 1994; Griffin et al., 1999), the lithospheric mantle is generally characterized by low $\mathrm{Rb} / \mathrm{Sr}$ and $\mathrm{Sm} / \mathrm{Nd}$ as well as an EM1-like isotopic signature. On the other hand, EM2-like mantle reservoir is located beneath circumcratonic terrains where crustal material had been recycled into the mantle through plate subduction (Boyd, 1989), while beneath tectonically mobile Phanerozoic belts are MORBOIB kind of mantle reservoirs (Menzies, 1989). However, in some tectonically remobilized regions such as in the eastern NCB, a decoupling phenomenon between exposed crustal rocks and subcrustal mantle had occurred. This has been regarded as a

*Corresponding author (e-mail: guofengt@263.net)

*Present address: Changsha Institute of Geotectonics, Chinese Academy of Sciences, 96 Tongzipo Road, Changsha 410013, P.R. China 
result of lithospheric thinning or replacement by newly-accreted MORB-like mantle (Fan and Menzies, 1992; Fan et al., 2000; Menzies et al., 1993; Zheng et al., 2001; Xu et al., 1995; Griffin et al., 1998; Xu et al., 2000). To understand how lithospheric mantle was removed is crucial for understanding continental mantle accretion and reworking processes, and basalt generation.

The NCB is known as one of the oldest continental blocks with recorded crustal age $>3.8 \mathrm{Ga}$ (Liu et al., 1992). The occurrence of Ordovician kimberlite-hosted diamonds and mantle xenoliths suggests the survival of an Archean lithsopehric keel that extended into the diamond stability filed (180-200 km) prior to the early Paleozoic. In contrast, the NCB upper mantle in Cenozoic time has been mainly composed of chemically fertile peridotites with MORB-OIB-like $\mathrm{Sr}-\mathrm{Nd}$ isotopic compositions at 70-80 km depth, showing similar characteristics to oceanic basins and tectonically mobile belts (e.g., Fan et al., 2000; Menzies et al., 1993; Griffin et al., 1998; Xu et al., 2000; Zheng et al., 2001; Yuan, 1996). This means that at least $100 \mathrm{~km}$ of lithosphere in NCB was lost during the last 400 million years. Comparative studies between early Paleozoic and Cenozoic upper mantle indicate that the lost lithospheric mantle should have geochemical characteristics similar to that of the Archean lithospheric keel, but this has not been confirmed in most previous studies.

As an important stage for lithospheric evolution in NCB, undoubtedly, the nature of Mesozoic lithospheric mantle is of great importance in discussing the following questions: (1) What kind of mantle reservoir was predominantly removed?, and (2) How did the lithospheric thinning process proceed? Generally, lithospheric mantle can be well constrained through geochemical investigations on mantle xenoliths and mantle-derived magmatism. Due to the absence of Mesozoic mantle xenoliths, Guo et al. (2001) carried out geochemical investigations on the late Mesozoic mafic intrusions in west Shandong Province, which were derived from decompressional melting of phlogopite-bearing garnet harzburgites with
EM1-like Sr and Nd isotopic ratios. Another question arising is whether this kind of enriched mantle reservoir was predominant beneath the NCB during Mesozoic time or it was only retained as a residue after the majority of the Archean keel had been removed. In order to characterize the lost lithospheric mantle and to probe by what means the lithospheric mantle was digested, we present new geochemical and isotopic data of basaltic lavas for Zouping in west Shandong Province, and integrate the published data of roughly contemporaneous mafic intrusions from Jinan and Zouping. One of our aims is focused on the source characteristics of these Mesozoic mafic rocks so that we can identify the Mesozoic SCLM from that prevalent in the early Paleozoic and Cenozoic. Besides this, an attempt to understand the lithospheric thinning process and its relationship with the Mesozoic melting event is also involved in this paper.

\section{GEOLOGICAL BACKGROUND AND PETROgraphy}

The general geology of the NCB has been widely introduced in the previous publications (e.g., Fan et al., 2000; Guo et al., 2001; Griffin et al., 1998; Wang et al., 1998; Zheng, 1999). Generally, the basement consists of Archean to early Proterozoic high-grade metamorphic rocks. As revealed by studies of the early Paleozoic kimberlite-hosted diamonds from Mengyin and Fuxian, a cold and thick Archean lithospheric keel existed beneath the NCB. During the late Mesozoic, the NCB was remobilized in response to extensional tectonics (Ma, 1989), resulting in the formation of a series of NE-trending fault basins accompanied by the emplacement of voluminous granitic plutons and mafic magmas as well as large-scale metal metallogeny. The lithospheric extension in this area attained its highest level during the early Tertiary, followed by the opening of Bohai Bay and extensive eruption of tholeiitic lavas in the rift basins. The amount of extension has diminished and only scattered volcanism has occurred since the Neogene. 

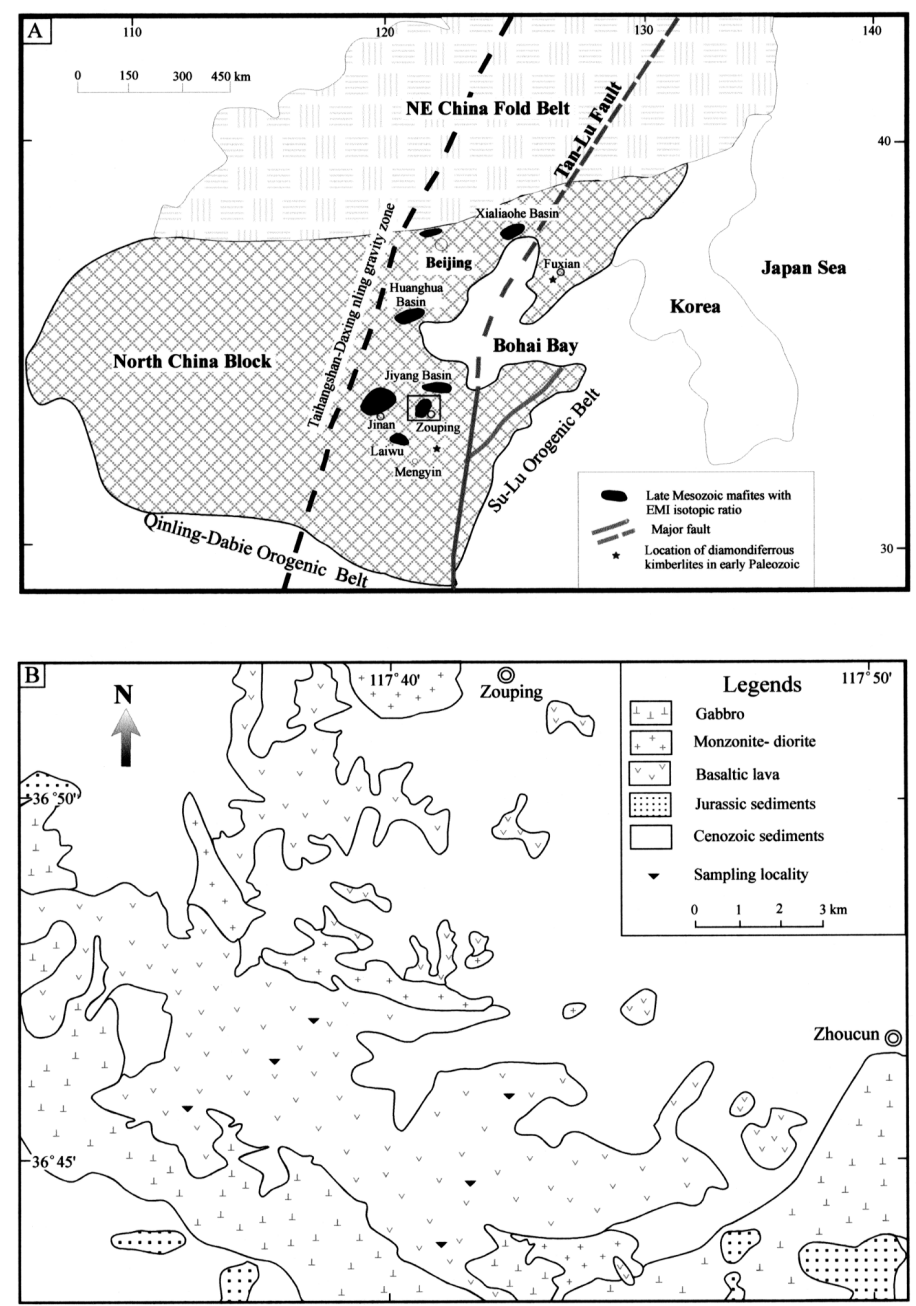

Fig. 1. Distribution of late Mesozoic mafic magmatism in the North China Block (A) and geological map of the early Cretaceous Zouping basaltic lavas (B). Data sources: Xialiaohe Basin (Zhou et al., 2001); Jiyang and Huanghua basins (Fan's unpublished data); Jinan and Zouping mafic intrusions (Guo et al., 2001); Yanshan mafic sills (Shao et al., 2001); Laiwu gabbroic diorite (Chi et al., 1994); the early Paleozoic kimberlites (Zheng, 1999; Chi and Lu, 1996); Zouping basaltic lavas (this study).

The west Shandong Province is located west of the Tan-Lu Fault within the NCB (Fig. 1A). Late Mesozoic mafic rocks are widely distributed in the NCB, such as in Yanshanian Orogen (Shao et al., 2001), Xialiaohe Basin (Zhou et al., 2001), Jiyang and Huanghua basins (Fan's unpublished data), west Shandong Province including Jinan (Guo et al., 2001), Zouping, Laiwu, and Mengyin (Chi et al., 1994). At Zouping (Fig. 1B), the late Mesozoic volcanics are bounded by Qingshan
Formation and whole-rock K-Ar dating result shows that these volcanic sequence were erupted at 128 130 Ma (Regional Geological Survey of Shandong Province, 1991). They comprise mainly basaltic trachyandesites and minor trachyandesites. The volcanic sequence crops out in subhorizontal layers of hundreds of meters thick, overlying unconformably the late Jurassic sandstones and shales or are intruded by late Mesozoic mafic intrusions of $115 \mathrm{Ma}$ (Tan and 
Lin, 1994; Lin et al., 1996). Basaltic samples are very fresh, commonly exhibiting aphanitic to weakly porphyritic texture with phenocrysts of clinopyroxene and olivine at 1 to $2 \mathrm{~mm}$ grain sizes, whereas plagioclase phenocrysts are rare. The groundmass is mainly composed of fine-grained clinopyroxene and plagioclase $(<0.2 \mathrm{~mm})$ and a few opaque oxides like ilmenite and magnetite.

\section{AnAlytical TeChNiQues}

All samples were crushed to mm-scale chips after removal of weathered rims and handpicked under a magnifier. Only fresh chips were selected and washed by pure water in an ultrasonic bath. Then these chips were crushed to $<20$ mesh in a WC jaw crusher. A split was ground to $<160$ mesh grain size in an agate ring mill, and this material was used for major and trace element analyses. Major element analysis was carried out by a wet chemical method at Changsha Institute of Geotectonics, with analytical errors less than $2 \%$. Trace element ICP-MS analysis was performed at the Institute of Geology and Geophysics (IGG), Chinese Academy of Sciences (CAS). Reproducibility is better than $95 \%$, and the analytical error is generally less than $5 \%$ for elements $>10 \mathrm{ppm}$ and less than $8 \%$ for those $<10 \mathrm{ppm}$.

$\mathrm{Sr}$ and $\mathrm{Nd}$ isotopic ratios were measured at IGG, CAS. The <20 mesh rock chips were leached by purified $6 \mathrm{~N} \mathrm{HCl}$ for 24 hours at room temperature before dissolution. $\mathrm{Sr}$ and $\mathrm{Nd}$ isotopic ratios were analyzed by a Mass Spectrum VG354 and were respectively normalized to ${ }^{86} \mathrm{Sr} /{ }^{88} \mathrm{Sr}=0.1194$ and ${ }^{146} \mathrm{Nd} /{ }^{144} \mathrm{Nd}=0.7219$. For detailed description of the isotope analytical procedure, refer to Guo et al. (2001). The analytical results for $\mathrm{Nd}$ isotopic ratio of standard sample JMC is $0.511139 \pm 10(n=6)$ and $\mathrm{Sr}$ isotopic ratios of NBS-987 is ${ }^{87} \mathrm{Sr} /{ }^{86} \mathrm{Sr}=0.710250 \pm 10(n=10)$, with whole procedure blanks lower than $5 \times 10^{-10}$ $\mathrm{g}$ for $\mathrm{Sr}$ and about $5 \times 10^{-11} \mathrm{~g}$ for Nd. The analytical errors for the $\mathrm{Sr}$ and $\mathrm{Nd}$ isotopic ratios are given by $2 \sigma$ and ${ }^{87} \mathrm{Rb} /{ }^{86} \mathrm{Sr}$ and ${ }^{147} \mathrm{Sm} /{ }^{144} \mathrm{Nd}$ ratios were calculated using the Rb, Sr, Sm and Nd abundance measured by the ICP-MS analysis. The ini- tial $\mathrm{Sr}-\mathrm{Nd}$ isotope ratios for basaltic lavas are corrected using a K-Ar age of $130 \mathrm{Ma}$.

\section{RESUlTS}

Major, trace element and Sr-Nd isotope data of late Mesozoic basaltic lavas from Zouping are listed in Table 1. In order to characterize these Mesozoic basaltic rocks, we carry out a comparative study between the mafic intrusions reported by Guo et al. (2001) and basaltic lavas in west Shandong Province. Some remarkable geochemical and isotopic features are summarized below.

1. Both mafic intrusive and volcanic rocks in west Shandong province exhibit a low Ti character with the highest $\mathrm{TiO}_{2}$ of $1.14 \%$ (Fig. 2). The Zouping volcanic rocks generally have $\mathrm{Mg \#}$ values less than $0.60\left(\mathrm{Mg} \#=\mathrm{Mg} /\left(\mathrm{Mg}+\sum \mathrm{Fe}\right)\right.$ in atomic ratio) and are magmatically evolved with regard to the contemporaneous mafic intrusions. Compared with mafic intrusions, the volcanic samples have relatively higher $\mathrm{SiO}_{2}$ and lower $\mathrm{MgO}$ contents (spanning a $\mathrm{SiO}_{2}$ range from 53.0 to $56.30 \%$ with $\mathrm{MgO}$ of $3.78 \sim 6.16 \%$ ) but higher incompatible element concentrations such as $\mathrm{K}$, (also Rb), Zr (also Nb, Hf) and Th (also U) (Figs. $2 \mathrm{~d}, \mathrm{~h}$ and $\mathrm{j}$ ). The lower compatible element abundance like $\mathrm{Fe}$ and $\mathrm{Cr}$ in the basaltic samples may be a result of olivine and pyroxene fractionation during magma evolution.

As illustrated in Figs. 2a, c, f, and 3, the positive correlation between $\mathrm{FeO} *\left(\right.$ as $\mathrm{FeO}+\mathrm{Fe}_{2} \mathrm{O}_{3}$ ), $\mathrm{CaO}, \mathrm{Cr}, \mathrm{CaO} / \mathrm{Al}_{2} \mathrm{O}_{3}$ and $\mathrm{MgO}$ indicate that olivine and clinopyroxene are the major fractionating phases during magma differentiation, whereas plagioclase fractionation plays a less important role on the basis of negative correlation between $\mathrm{Al}_{2} \mathrm{O}_{3}, \mathrm{Sr}$ and $\mathrm{MgO}$ (Figs. $2 \mathrm{~b}$ and $\mathrm{g}$ ). The high $\mathrm{Ba}$ contents in both volcanic and intrusive rocks as well as the random variation between $\mathrm{MgO}$ and $\mathrm{Ba}$ (Fig. 2i) might suggest the existence of phlogopite in the melting source.

2. Both mafic intrusions and volcanic samples show similar chondrite-normalized REE patterns with LREE enrichment and positive Eu anoma- 
Table 1. Major, trace element contents and Sr-Nd isotope data of the late Mesozoic basaltic lavas in west Shandong Province of the $N C B$

\begin{tabular}{|c|c|c|c|c|c|c|c|c|c|c|c|}
\hline Sample & 98ZP-5 & 98ZP-6 & 98ZP-7 & 98ZP-8 & 98ZP-9 & 98ZQ-1 & 98ZQ-3 & 97ZQ-5 & 98ZQ-8 & 98ZQ-9 & 98ZQ-13 \\
\hline $\mathrm{SiO}_{2}$ & 54.60 & 54.10 & 54.38 & 53.40 & 54.32 & 55.90 & 55.54 & 56.14 & 54.70 & 55.62 & 53.00 \\
\hline $\mathrm{Al}_{2} \mathrm{O}_{3}$ & 16.24 & 16.01 & 15.93 & 14.92 & 15.38 & 15.45 & 16.54 & 16.69 & 16.69 & 15.06 & 16.89 \\
\hline $\mathrm{Fe}_{2} \mathrm{O}_{3}$ & 2.95 & 2.87 & 3.25 & 6.35 & 3.99 & 5.21 & 3.68 & 3.33 & 3.07 & 4.76 & 3.92 \\
\hline $\mathrm{FeO}$ & 5.28 & 6.00 & 5.82 & 2.48 & 4.60 & 3.94 & 4.43 & 4.46 & 5.27 & 3.22 & 5.40 \\
\hline $\mathrm{CaO}$ & 6.87 & 7.58 & 6.98 & 6.18 & 7.31 & 6.25 & 3.82 & 7.05 & 6.98 & 7.31 & 7.80 \\
\hline $\mathrm{MgO}$ & 4.93 & 5.79 & 4.81 & 6.63 & 5.55 & 4.71 & 5.93 & 3.78 & 3.87 & 5.51 & 6.15 \\
\hline $\mathrm{K}_{2} \mathrm{O}$ & 1.55 & 1.06 & 2.24 & 2.89 & 2.65 & 1.67 & 1.53 & 2.54 & 3.31 & 1.87 & 1.56 \\
\hline $\mathrm{Na}_{2} \mathrm{O}$ & 3.55 & 3.81 & 3.28 & 3.78 & 3.17 & 4.29 & 4.66 & 3.59 & 3.39 & 3.91 & 3.28 \\
\hline $\mathrm{P}_{2} \mathrm{O}_{5}$ & 0.41 & 0.42 & 0.38 & 0.39 & 0.39 & 0.43 & 0.46 & 0.43 & 0.41 & 0.24 & 0.54 \\
\hline $\mathrm{MnO}$ & 0.12 & 0.14 & 0.16 & 0.14 & 0.14 & 0.13 & 0.12 & 0.15 & 0.15 & 0.08 & 0.14 \\
\hline $\mathrm{TiO}_{2}$ & 0.83 & 0.89 & 0.99 & 0.88 & 0.82 & 0.91 & 0.90 & 0.85 & 0.83 & 0.77 & 0.98 \\
\hline $\mathrm{LOS}^{2}$ & 1.34 & 1.38 & 1.22 & 1.58 & 1.26 & 0.60 & 1.02 & 0.82 & 0.42 & 0.72 & 0.50 \\
\hline Total & 98.67 & 100.05 & 99.44 & 99.62 & 99.58 & 99.49 & 98.63 & 99.83 & 99.09 & 99.07 & 100.16 \\
\hline Mg\# & 0.53 & 0.55 & 0.50 & 0.59 & 0.55 & 0.50 & 0.58 & 0.48 & 0.46 & 0.57 & 0.55 \\
\hline $\mathrm{Cr}$ & 235.5 & 111.2 & 58.16 & 501.7 & 226.6 & 158.4 & 124.6 & 167.0 & 116.5 & 108.8 & 326.9 \\
\hline $\mathrm{Rb}$ & 44.93 & 33.18 & 63.64 & 82.72 & 56.12 & 41.69 & 109.7 & 67.01 & 90.24 & 37.23 & 56.18 \\
\hline $\mathrm{Sr}$ & 801 & 822 & 664 & 932 & 807 & 653 & 872 & 751 & 943 & 566 & 723 \\
\hline $\mathrm{Nb}$ & 8.21 & 10.80 & 8.93 & 10.54 & 9.62 & 11.48 & 20.17 & 12.59 & 11.46 & 8.90 & 10.94 \\
\hline $\mathrm{Ba}$ & 5010 & 3088 & 3011 & 2769 & 3470 & 2097 & 2944 & 2660 & 3073 & 2261 & 2925 \\
\hline $\mathrm{Zr}$ & 185 & 117 & 94 & 139 & 134 & 104 & 201 & 129 & 140 & 87 & 111 \\
\hline $\mathrm{Hf}$ & 3.91 & 2.60 & 1.98 & 3.44 & 2.98 & 2.22 & 4.72 & 2.93 & 3.00 & 2.05 & 2.64 \\
\hline Th & 2.57 & 2.72 & 2.50 & 2.37 & 2.54 & 3.31 & 11.89 & 4.55 & 2.65 & 2.31 & 2.57 \\
\hline $\mathrm{U}$ & 0.75 & 0.91 & 0.50 & 0.78 & 0.74 & 0.87 & 3.56 & 1.34 & 0.85 & 0.70 & 0.73 \\
\hline $\mathrm{Y}$ & 15.34 & 17.04 & 14.89 & 16.8 & 16.02 & 17.41 & 16.53 & 18.05 & 19.53 & 16.88 & 19.91 \\
\hline $\mathrm{La}$ & 22.09 & 24.28 & 18.08 & 21.18 & 21.41 & 24.66 & 31.85 & 24.39 & 25.46 & 16.16 & 23.82 \\
\hline $\mathrm{Ce}$ & 46.29 & 52.04 & 40.34 & 43.07 & 45.44 & 48.74 & 63.82 & 51.73 & 54.26 & 38.83 & 53.01 \\
\hline $\mathrm{Pr}$ & 5.72 & 6.18 & 4.62 & 5.97 & 5.62 & 6.18 & 6.84 & 6.22 & 6.67 & 4.80 & 6.62 \\
\hline $\mathrm{Nd}$ & 24.05 & 26.09 & 20.58 & 21.18 & 22.98 & 27.53 & 28.78 & 26.36 & 28.79 & 20.19 & 26.51 \\
\hline $\mathrm{Sm}$ & 5.14 & 4.78 & 4.84 & 5.52 & 5.07 & 5.78 & 4.03 & 5.15 & 6.82 & 3.79 & 5.31 \\
\hline $\mathrm{Eu}$ & 4.31 & 3.23 & 2.75 & 2.56 & 3.21 & 2.87 & 3.08 & 2.80 & 3.43 & 2.00 & 2.62 \\
\hline $\mathrm{Gd}$ & 3.97 & 5.15 & 3.63 & 5.30 & 4.51 & 5.18 & 5.49 & 5.50 & 6.15 & 4.45 & 6.21 \\
\hline $\mathrm{Tb}$ & 0.58 & 0.64 & 0.45 & 0.60 & 0.57 & 0.71 & 0.62 & 0.67 & 0.72 & 0.57 & 0.72 \\
\hline Dy & 2.61 & 3.25 & 2.04 & 3.49 & 2.85 & 2.78 & 2.79 & 3.30 & 3.94 & 3.21 & 3.76 \\
\hline Ho & 0.56 & 0.59 & 0.63 & 0.69 & 0.62 & 0.73 & 0.58 & 0.70 & 0.84 & 0.58 & 0.76 \\
\hline $\mathrm{Er}$ & 1.49 & 2.29 & 1.25 & 1.63 & 1.67 & 1.69 & 1.54 & 1.65 & 1.67 & 1.51 & 1.86 \\
\hline $\mathrm{Tm}$ & 0.25 & 0.29 & 0.17 & 0.26 & 0.24 & 0.38 & 0.23 & 0.27 & 0.27 & 0.22 & 0.25 \\
\hline $\mathrm{Yb}$ & 1.01 & 1.76 & 1.18 & 1.19 & 1.29 & 1.26 & 1.52 & 1.48 & 1.80 & 1.27 & 1.54 \\
\hline $\mathrm{Lu}$ & 0.13 & 0.23 & 0.18 & 0.29 & 0.21 & 0.21 & 0.20 & 0.22 & 0.25 & 0.21 & 0.23 \\
\hline $\mathrm{Eu}^{*} / \mathrm{Eu}$ & 2.82 & 1.98 & 1.92 & 1.43 & 2.04 & 1.68 & 2.00 & 1.63 & 1.59 & 1.48 & 1.39 \\
\hline${ }^{87} \mathrm{Rb} /{ }^{86} \mathrm{Sr}$ & 0.1607 & 0.1167 & 0.2773 & 0.2568 & 0.2013 & 0.1846 & 0.3641 & 0.2581 & 0.2768 & 0.1905 & 0.2249 \\
\hline${ }^{87} \mathrm{Sr} /{ }^{86} \mathrm{Sr}$ & 0.70495 & 0.70485 & 0.70515 & 0.70525 & 0.70504 & 0.70513 & 0.70493 & 0.70498 & 0.70524 & 0.70566 & 0.70438 \\
\hline $\pm 2 \sigma$ & \pm 2 & \pm 1 & \pm 2 & \pm 3 & \pm 1 & \pm 2 & \pm 4 & \pm 3 & \pm 1 & \pm 2 & \pm 2 \\
\hline${ }^{87} \mathrm{Sr} /{ }^{86} \mathrm{Sr}(\mathrm{i})$ & 0.70468 & 0.70465 & 0.70468 & 0.70481 & 0.70470 & 0.70482 & 0.70431 & 0.70454 & 0.70477 & 0.70534 & 0.70400 \\
\hline${ }^{147} \mathrm{Sm} /{ }^{144} \mathrm{Nd}$ & 0.1292 & 0.1108 & 0.1422 & 0.1575 & 0.1334 & 0.1269 & 0.0846 & 0.1180 & 0.1432 & 0.1135 & 0.1211 \\
\hline${ }^{143} \mathrm{Nd} /{ }^{144} \mathrm{Nd}$ & 0.511750 & 0.511756 & 0.511838 & 0.511946 & 0.511808 & 0.511748 & 0.511739 & 0.511797 & 0.511755 & 0.511866 & 0.511810 \\
\hline $\pm 2 \sigma$ & \pm 8 & \pm 7 & \pm 10 & \pm 19 & \pm 6 & \pm 9 & \pm 10 & \pm 11 & \pm 8 & \pm 9 & \pm 15 \\
\hline$\varepsilon_{\mathrm{Nd}}(\mathrm{t})$ & -16.30 & -15.90 & -14.78 & -12.91 & -15.23 & -16.31 & -15.83 & -15.21 & -16.42 & -13.80 & -15.01 \\
\hline
\end{tabular}

Note: The initial Sr and Nd isotope ratios are corrected using the age of $130 \mathrm{Ma} . \mathrm{Mg \#}=\mathrm{Mg} /(\mathrm{Mg}+\mathrm{\Sigma Fe})$ in atomic ratio.

lies (Fig. 4a). In general, the volcanic samples have stronger LREE/HREE ratio and HREE fractionation than the intrusions $\left(\mathrm{La} / \mathrm{Yb}_{\mathrm{CN}}=8.60\right.$ 14.78 and $\mathrm{Gd} / \mathrm{Yb}_{\mathrm{CN}}=2.37-3.61$ for basaltic lavas and $3.72-12.23$ and $1.97-3.20$ for mafic intru- sions, respectively), possibly suggesting a more important role for garnet and/or smaller melting degree in the generation of the primary magmas for Zouping basaltic lavas. 

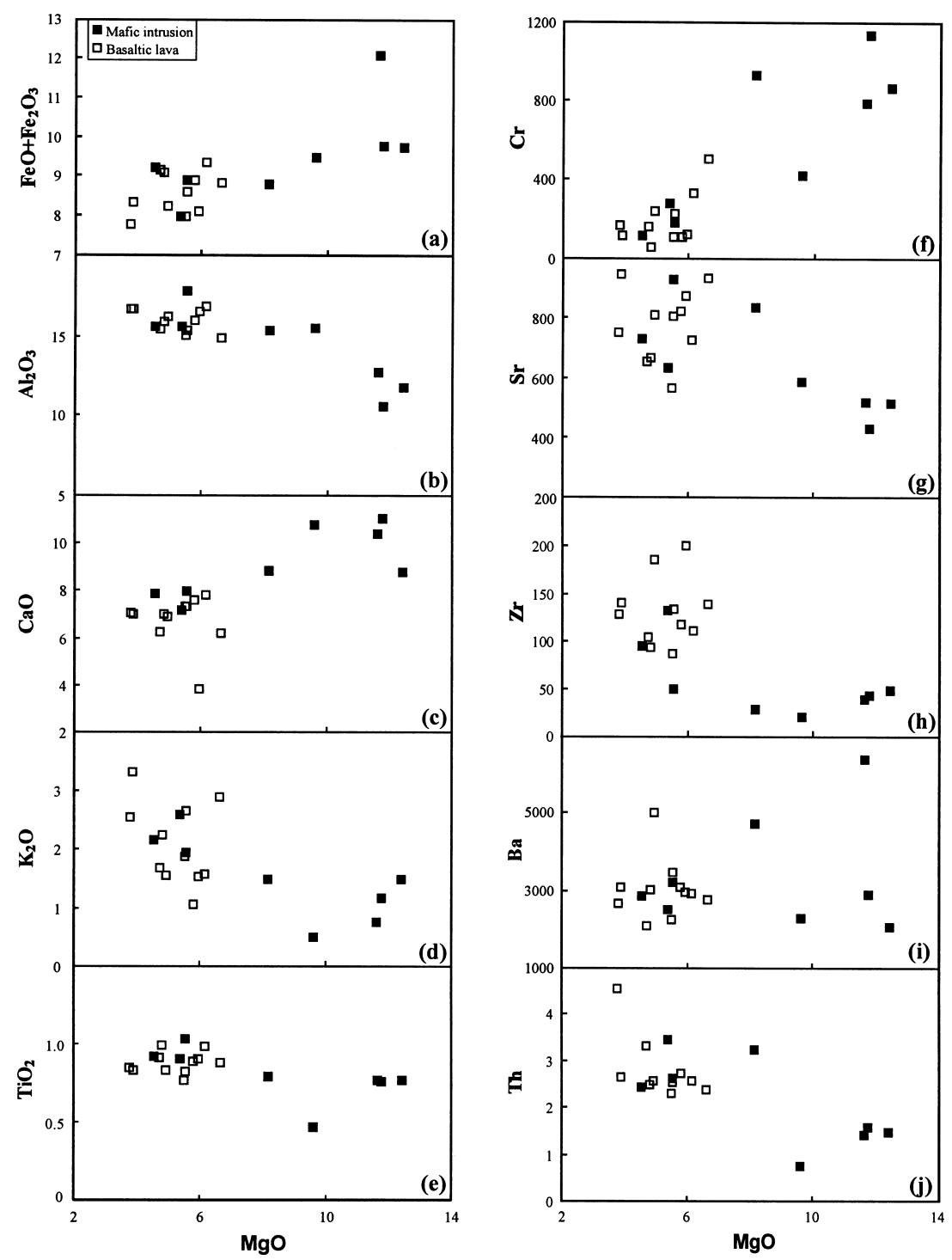

Fig. 2. Variation diagrams for major oxides and trace elements vs. $M g O$ contents for mafic rocks in west Shandong Province. It is clear that Zouping basaltic lavas have higher contents of "mantle-incompatible" elements such as $K, \mathrm{Rb}, \mathrm{P}, \mathrm{Ti}$ and $\mathrm{Zr}, \mathrm{Nb}$ and lower compatible element abundance such as $\mathrm{Fe}, \mathrm{Cr}$ than the intrusive samples. Data of mafic intrusions are from Guo et al. (2001).

A remarkable feature observed in their primitive mantle-normalized spidergrams is that these rocks are characterized by LILE, LREE enrichment (such as $\mathrm{Ba}, \mathrm{Sr}$ and $\mathrm{K}$ ) and significantly negative HFSE (Nb, Zr, Hf and Ti) anomalies (Fig. $4 \mathrm{~b}$ ), completely distinguishable from most intraplate volcanic rocks like MORB, OIB, alkali basalts and kimberlites that usually show no or insignificant HFSE anomalies (Sun and McDonough, 1989). In addition, a long-term LILE and LREE enrichment relative to HFSE in the melting source before magma generation can be inferred from their high $\mathrm{Ba} / \mathrm{Nb}$ and $\mathrm{La} / \mathrm{Nb}$ (Guo et al., 2001; Zhou et al., 2001; Shao et al., 2001). 


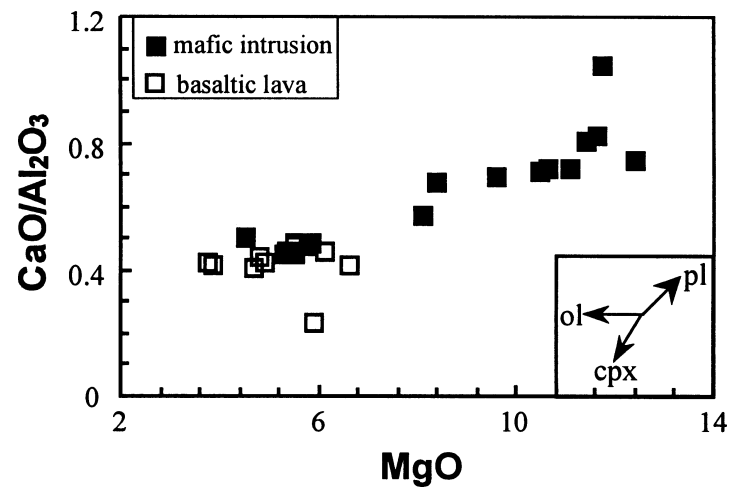

Fig. 3. $\mathrm{MgO}$ vs. $\mathrm{CaO} / \mathrm{Al}_{2} \mathrm{O}_{3}$ plots for late Mesozoic mafic rocks, showing an important role of olivine and clinopyroxene fractionation during magmatic evolution.
3. Both intrusive and volcanic rocks in west Shandong Province have an EM1-like signature (the initial ${ }^{87} \mathrm{Sr} /{ }^{86} \mathrm{Sr}(\mathrm{i})=0.7040$ to 0.70546 and $\varepsilon_{\mathrm{Nd}}(\mathrm{i})=-18.9$ to -9.2 ) (Table 1 and Fig. 5), similar to Mesozoic mafic rocks from adjacent areas within the NCB (Zhou et al., 2001; Shao et al., 2001; Fan's unpublished data). With regard to the early Paleozoic kimberlites and mantle xenoliths (Zheng, 1999; Chi and Lu, 1996), they generally show relatively lower initial ${ }^{143} \mathrm{Nd} /{ }^{144} \mathrm{Nd}$ and ${ }^{87} \mathrm{Sr} /$ ${ }^{86} \mathrm{Sr}$ ratios. It is likely that these mafic magmas originated from partial melting of an enriched mantle reservoir, in which a LREE enrichment process had occurred to produce the highly nega-
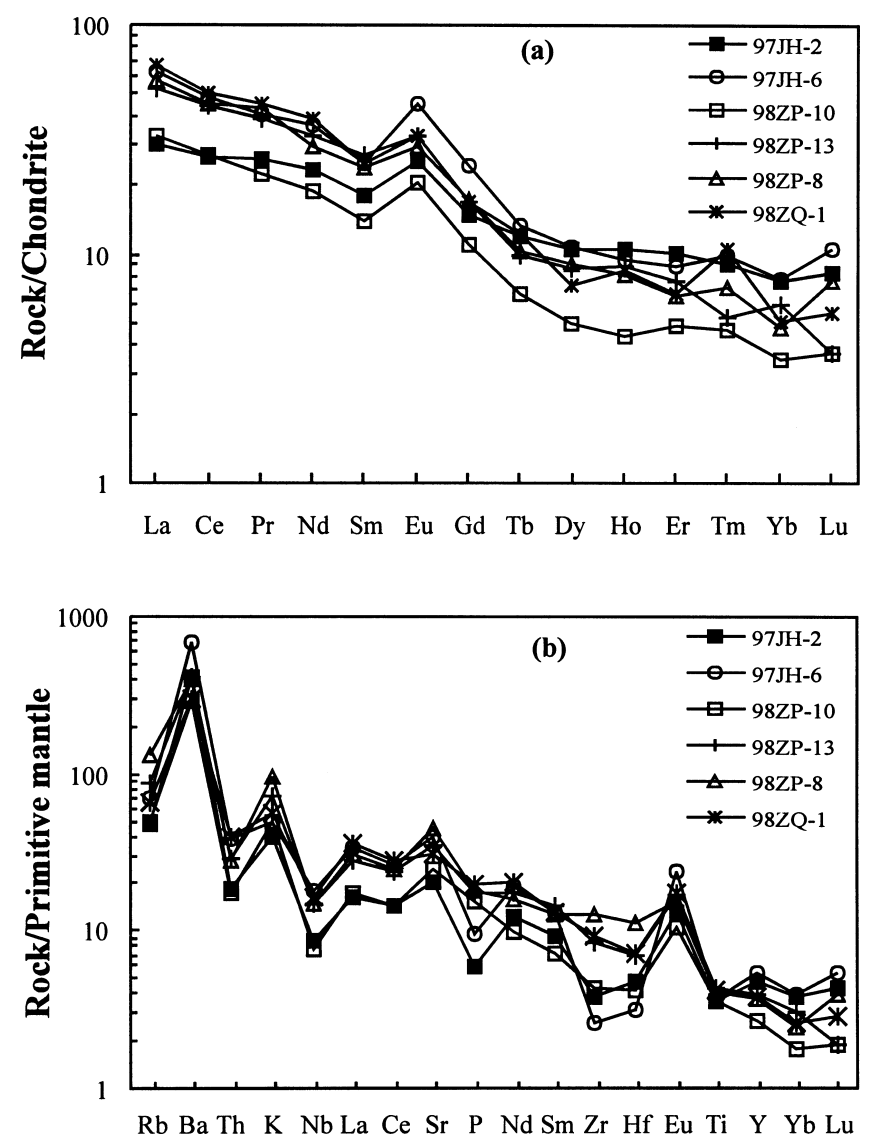

Fig. 4. Chondrite-normalized REE patterns (a) and primitive mantle-normalized spidergrams (b) of late Mesozoic mafic rocks. (a) shows that both the intrusive and volcanic samples have LREE enrichment and positive Eu anomalies, whereas LILE and LREE enrichment and HFSE depletion are evident for all mafic rocks in (b). REE contents (in ppm) for chondrite are from Taylor and McLennan (1985) and trace element abundance (in ppm) for primitive mantle are from Sun and McDonough (1989). 


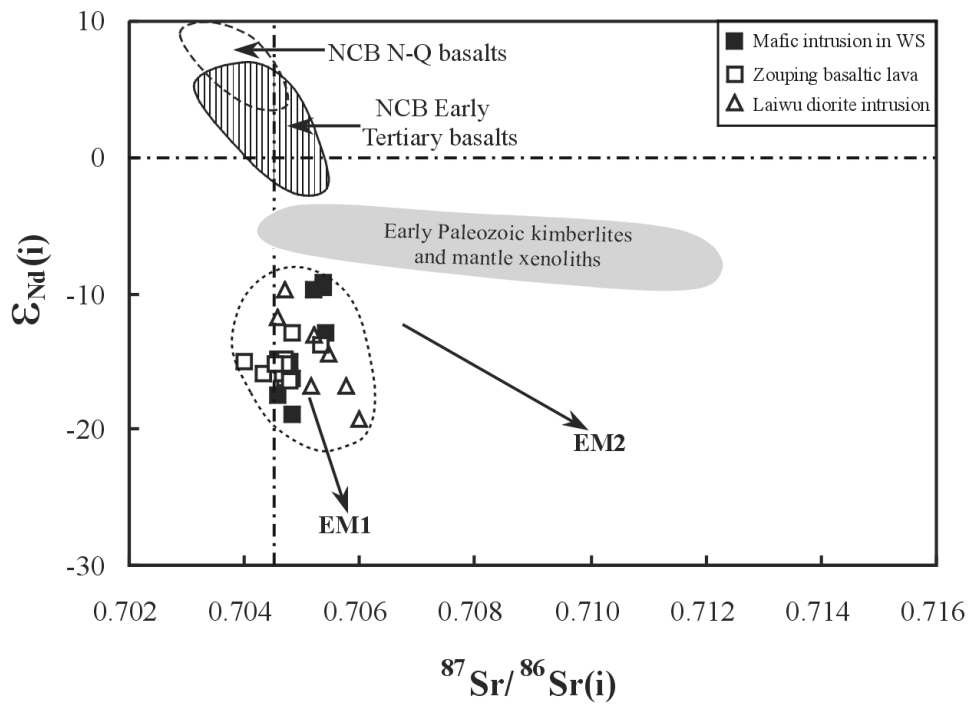

Fig. 5. $\varepsilon_{N d}(i)$ vs. initial ${ }^{87} \mathrm{Sr} /{ }^{86} \mathrm{Sr}(\mathrm{i})$ variation diagram for late Mesozoic mafic rocks. All late Mesozoic mafic rocks are displaced toward an EM1-component, consistent with an aged and enriched mantle source in their origin. Data sources: mafic intrusions in WS (Guo et al., 2001); Zouping basaltic lavas (this study); Gabbroic diorite at Laiwu (Chi et al., 1994). Isotope data of early Tertiary basin basalts, $N$ - $Q$ basalts and early Paleozoic kimberlites and mantle xenoliths are from Zheng (1999) and references therein.
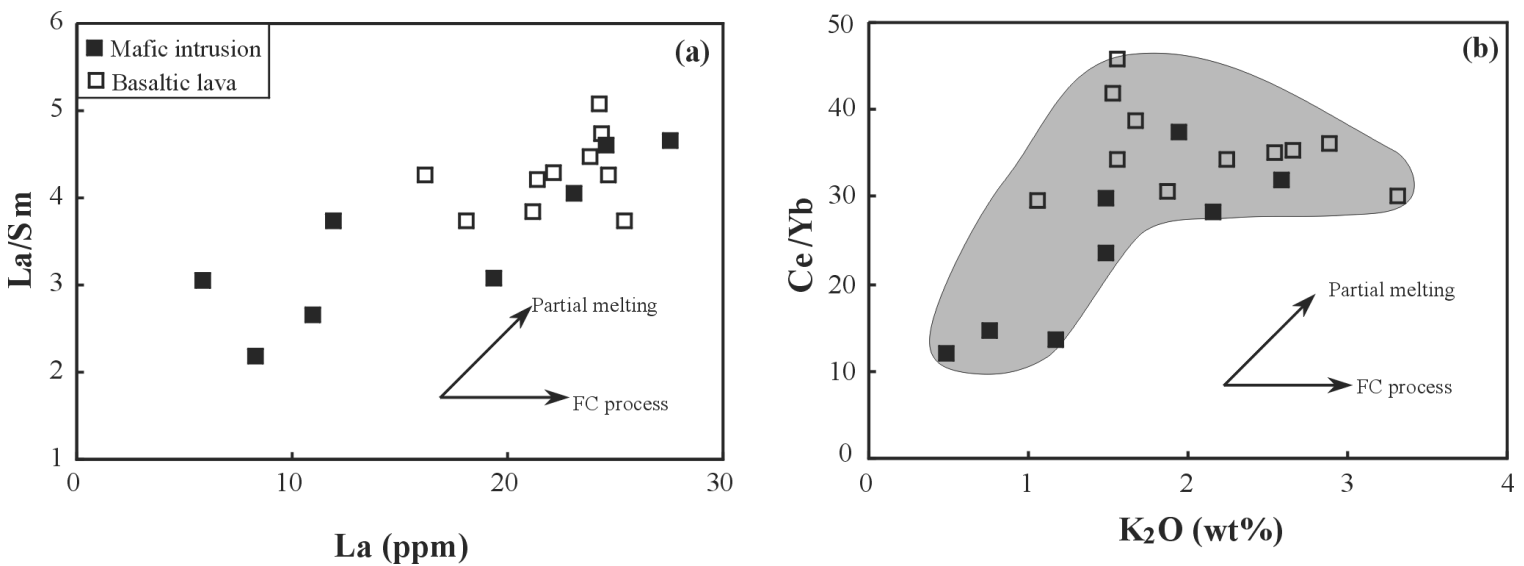

Fig. 6. Variation trends of La vs. La/Sm (a) and $\mathrm{K}_{2} \mathrm{O} v \mathrm{vs}$. Ce/Yb (b), showing that variation in partial melting may play more important role than fractional crystallization $(F C)$ in the magmatic evolution of the mafic rocks in west Shandong Province.

tive $\varepsilon_{\mathrm{Nd}}(\mathrm{i})$ values some time before the melting event. On the other hand, the slightly enriched to weakly depleted $\mathrm{Sr}$ isotopic ratios imply that the melting sources were not dramatically enriched in $\mathrm{Rb}$, i.e., the LILE enrichment process might occur during or shortly before the melting event (Guo et al., 2001).

4. Despite the similar geochemical and $\mathrm{Sr}-\mathrm{Nd}$ isotopic features of basaltic lavas and gabbros, both of them were not comagmatic. Field evidence 
and geochronological data show that the basaltic lavas were erupted earlier than the emplacement age. As shown in Fig. 6, the covariance between $\mathrm{La}$ and $\mathrm{La} / \mathrm{Sm}$ as well as $\mathrm{K}_{2} \mathrm{O}$ and $\mathrm{Ce} / \mathrm{Yb}$ suggest that the basaltic lavas were derived from a smaller melting degree of the mantle source than the liquids forming the mafic intrusions, corresponding to their stronger LREE/HREE and HREE fractionation. Most likely, both of mafic intrusive and volcanic rocks were derived from a similar source, but were generated through different melting degree.

\section{DISCUSSIONS}

Mantle source for late Mesozoic basaltic magmas in $N C B$

A remarkable feature of the late Mesozoic mafic rocks in west Shandong province is that all of them show LILE, LREE enrichment and significant HFSE depletion as well as EM1-like Sr$\mathrm{Nd}$ isotopic ratios, completely different from MORB-OIB, island arc basalt (IAB) and continental flood basalt (CFB). Previous studies of late Mesozoic mafic igneous rocks revealed that most samples have escaped significant crustal contamination during magma ascent and their geochemical and isotopic features were mainly inherited from their mantle sources (Guo et al., 2001; Shao et al., 2001; Zhou et al., 2001). For Zouping basaltic lavas, the fact that they exhibit lower initial $\mathrm{Sr}$ isotopic ratios than the younger mafic intrusions (despite their evolved nature) tends to indicate that contribution from crustal contamination in their origin may be negligible; thus their unusual geochemical and isotopic characteristics were mainly determined by partial melting degree and source characteristics.

The highly negative HFSE anomalies and $\varepsilon_{\mathrm{Nd}}(\mathrm{i})$ values of the mafic rocks in the NCB required a long-term LREE enrichment relative to HFSE before magma generation, which probably resulted from long-term metasomatism by $\mathrm{CO}_{2}$ rich fluids/melts as illustrated in a $\mathrm{Zr} / \mathrm{Sm}$ vs. Hf/ Sm variation diagram (Fig. 7) (Dupuy et al., 1992; Furman, 1995; Yaxley et al., 1991). This is also

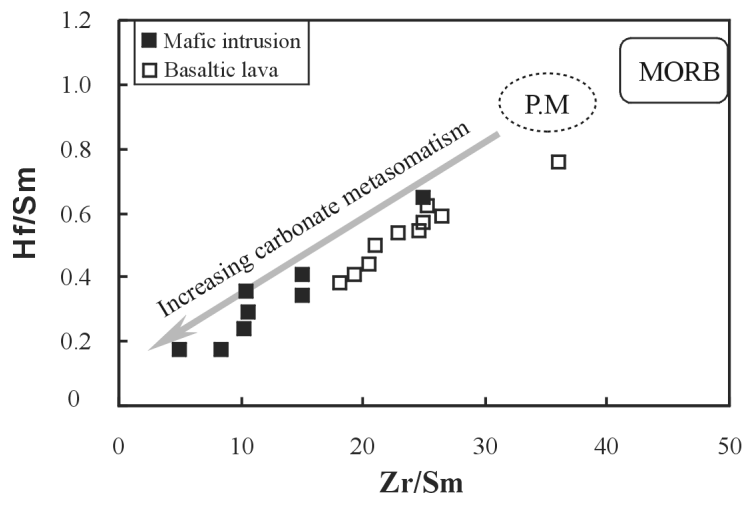

Fig. 7. $\mathrm{Zr} / \mathrm{Sm}$ versus $H f / S m$ variation diagram of the mafic rocks, showing a positive correlation between them, which appears to favor involvement of carbonatitic metasomatism in the source before magma generation (Dupuy et al., 1992). Data of PM and MORB refer to Sun and McDonough (1989).

supported by the occurrence of Mesozoic carbonate magmatism in NCB, such as at Laiwu basin, Datong and other areas (Shao, personal communication) and the prevalence of $\mathrm{CO}_{2}$-rich fluid inclusions in diamonds (Zheng, 1999). For a metasomatized lithospheric mantle, it is usually considered that disseminated amphibole and phlogopite in the lithospheric mantle generally has HFSE depletion relative to LREE, whereas veined phlogopite has no or insignificant HFSE anomalies (Bedini et al., 1997; Foley et al., 1996; Ionov et al., 1997). The $\mathrm{Sr}$ and $\mathrm{Nd}$ isotopic evolution depends on the modal proportion of clinopyroxene (cpx) and phlogopite (phlg) (Schmidt et al., 1999). For instance, cpx is responsible for the evolution of radiogenic $\mathrm{Nd}$ whereas $\mathrm{Sr}$ isotopic ratios depends on the modal proportion of $\mathrm{cpx} / \mathrm{phlg}$ since the influence of phlg on the Nd-isotope evolution is negligible because of its low partition coefficients for Sm and Nd (Ionov et al., 1997; Schmidt et al., 1999). Thus melts derived from veined phlgbearing peridotites will occupy distinguishable trace element and $\mathrm{Sr}-\mathrm{Nd}$ isotopic features (e.g., the degree of HFSE anomalies and initial Sr-Nd isotopic compositions) from those derived by melting of peridotites with disseminated phlogopite. 


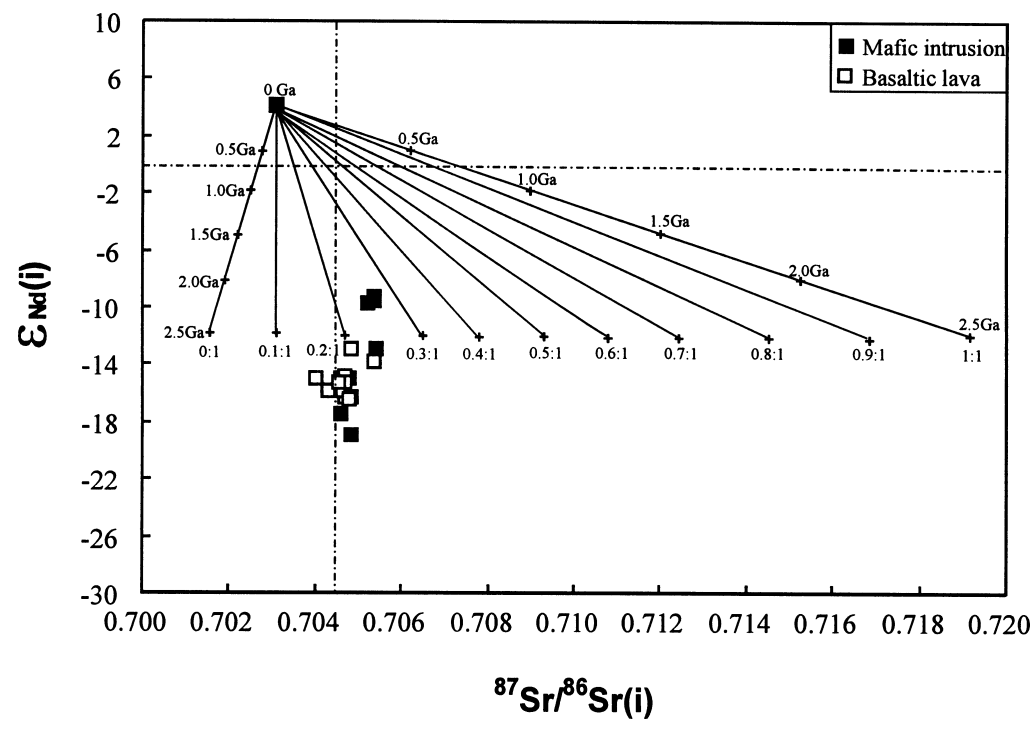

Fig. 8. $\varepsilon_{N d}(i) v s$. initial ${ }^{87} \mathrm{Sr} /{ }^{86} \mathrm{Sr}(\mathrm{i})$ plots as an indicator of $\mathrm{Sr}$ and $\mathrm{Nd}$ isotopic evolution corresponding to modal proportion of cpx/phlg (according to Schmidt et al., 1999). The low ratio of phlg/cpx implies that disseminated rather than vein phlg existed in the melting source for the late Mesozoic NCB mafic magmatism.

Guo et al. (2001) noted that Mesozoic SCLM beneath NCB revealed by high-MgO mafic intrusions from Jinan and Zouping in west Shandong Province was mainly composed of chemically refractory peridotites with predominance of phlgbearing garnet harzburgites. Trace element partitioning coefficients ( $D$-values) for $\mathrm{Rb}, \mathrm{Sr}, \mathrm{Sm}$ and $\mathrm{Nd}$ between olivine, orthopyroxene, garnet, spinel (major phases in mantle peridotites) and melt are lower at least by a factor of 200 than those for phlg and cpx (Kennedy et al., 1993). When the content of phlg + cpx is above $5 \%$ in the lithospheric mantle, the contribution of these major peridotite phases to $\mathrm{Sm}, \mathrm{Nd}, \mathrm{Rb}$ and $\mathrm{Sr}$ in the mantle reservoir can be negligible. The slightly enriched to weakly depleted initial Sr isotopic ratios in these basaltic rocks imply that the modal proportion of $\mathrm{phlg} / \mathrm{cpx}$ spanned a range from $0.15: 1$ to $0.3: 1$ (Fig. 8). This means that phlogopite had been retained in the SCLM in disseminated form rather than in vein. Otherwise, the melting source for Mesozoic mafic rocks should have also developed extremely enriched $\mathrm{Sr}$ isotopic ratios and insignificant or no HFSE anomalies just like that for the early Paleozoic kimberlites (Bedini et al., 1997; Foley et al., 1996; Ionov et al., 1997; Chi and Lu, 1996).

\section{Comparison with Cenozoic and early Paleozoic lithospheric mantle}

The Cenozoic upper mantle in NCB is mainly composed of chemically fertile peridotites, which have MORB-OIB-like Sr-Nd isotopic compositions (Zheng, 1999; Fan et al., 2000; Griffin et al., 1992, 1998; Xu et al., 1995; Xu et al., 2000; Yuan, 1996), similar to the mantle reservoirs beneath oceanic basins and tectonically mobile areas. The majority of present upper mantle was considered to have formed through mantle accretion by extraction of mantle-derived magmas and/ or replacement by newly-accreted peridotites in response to lithospheric thinning process and basaltic generation. It is evident that the Mesozoic SCLM beneath the NCB is completely different from that in Cenozoic both in lithological associations and isotopic features. This means that the ancient and enriched lithospheric mantle had been almost entirely removed during the late Mesozoic to Cenozoic thinning.

Wang et al. (1998) and Zheng (1999) reported 
that the early Paleozoic lithospheric mantle comprised mainly chemically refractory and isotopically EM2-like garnet lherzolites, harzburgites and eclogites with similar lithological associations to Archean lithospheric keels such as in the Kapavaal, Wyoming, Siberia and Slave Cratons (Menzies, 1989; Pearson et al., 1995; Walker et al., 1989; Griffin et al., 1999; Carlson and Irving, 1994). However, these early Paleozoic kimberlites and mantle xenoliths exhibit different geochemical and $\mathrm{Sr}-\mathrm{Nd}$ isotopic features from those Mesozoic basaltic rocks in that they have insignificant HFSE depletion as well as EM2-like Sr-Nd isotopic compositions (Zheng, 1999; Chi and Lu, 1996). The observed geochemical and isotopic differences between the melting sources for early Paleozoic kimberlites and for late Mesozoic mafic magmatism can be explained as a result of different amounts of prior fluid/melt and wall-rock peridotite interaction.

It is usually accepted that veined amphibole and mica crystallize from melts or fluids in conduits whereas disseminated amphibole and mica form as a result of reaction of host peridotites with fluids or melts in vicinity of the veins or due to pervasive fluid/melt percolation. According to Zheng (1999) and Wang et al. (1998), P-T estimate shows that most of the mantle xenoliths hosted in kimberlites equilibrated at depths $>120$ $\mathrm{km}$. This implies that most of these mantle xenoliths might represent the lowermost part of the Archean lithospheric keel. As revealed by the early Ordovician diamond-bearing kimberlites, the lithosphere beneath NCB was cold and thick during or before the early Paleozoic (Menzies et al., 1993; Griffin et al., 1998; Chi and Lu, 1996). In such environments, low-volume of mantle-derived melts are usually carbonatitic to kimberlitic at high pressures, and are generated through very small degrees (up to $1 \%$ ) of melting (Dalton and Presnall, 1998). This melt upwards for short distances and crystallizes in phlg veins at pressures greater than 3.0 GPa as it encounters the colder overlying lithosphere. Reaction between the melt components and peridotite wall rocks can produce inhomogeneous mixtures of phlg veins and peridotites (Foley, 1992). This is consistent with the strongly varied $\mathrm{Sr}$ isotope data observed in the early Paleozoic kimberlites and their entrained mantle xenoliths (Zheng, 1999; Chi and Lu, 1996). In comparison with the early Paleozoic kimberlites and their hosting xenoliths, the mantle source of late Mesozoic basaltic rocks was within the colder lithospheric mantle; diffusive melt/fluid metasomatism or pervasive fluid/melt percolation had occurred in the lithosphere to form the disseminated phlg due to the lowering of the amount of melt/fluid-wall rock interaction (Ionov et al., 1997; Schmidt et al., 1999). Melts derived from such a disseminated phlg mantle reservoir would have strong HFSE depletion relative to LILE and LREE.

\section{Implications for lithospheric thinning process in $N C B$}

Discussion of the lithospheric thinning process in the NCB has involved primarily: (1) whether the lithosphere was rapidly attenuated or progressively removed; and (2), what caused the extensive Mesozoic melting event. Gao et al. (1998) noted that the thick lithosphere beneath NCB had been rapidly delaminated, followed by emplacement of extensive mafic rocks and voluminous granitic plutons and associated large-scale metal metallogeny. However, numerical modeling shows that a compositionally distinct Archean lithospheric root consisting of depleted peridotite can grow and remain stable during a period of secular cooling, even within a hot convecting mantle due to its intrinsically lower density and temperature-dependent rheology (De Smet et al., 1999). Hence, it is difficult for chemically refractory peridotites with lower density to be destroyed or delaminated unless they have been impacted by an upwelling mantle plume or entrained by lithospheric thickening related to plate subduction or collision which triggers gravitational instability. According to geophysical observations (Engebretson et al., 1985; Yuan, 1996), there did not exist westerly-dipping subduction of the ancient Pacific Plate nor an abnormally hot mantle plume beneath NCB before the early Cretaceous. 
It is unlikely therefore that lithospheric thickening in response to plate subduction or impact by a mantle plume occurred during or shortly before the extensive melting event. Furthermore, as a consequence of lower crust and lithospheric mantle delamination, OIB-like melts should have appeared since the upwelling asthenosphere directly underlies the lower crust; upwelling asthenosphere would experience extensive melting in accordance with the melting model proposed by McKenzie and Bickle (1988). The absence of MORB or OIBlike magmas in the NCB appears to indicate that this sequence of events did not occur before the early Cretaceous.

Lateral escape tectonics were well developed in response to $\mathrm{NE}$-trending and $\mathrm{S}$-trending indentors respectively by the Indo-Sinian Block and Siberia Craton during the late Mesozoic (Menzies et al., 1993; Hacker et al., 2000; Ratschbacher et al., 2000); these indentors might have initiated the lithospheric extension as well as geothermal elevation from a cold and thick lithosphere into a hot, thin and rift-related one. During the early Cretaceous, the Tan-Lu wrench fault system was at its maximum sinistral strikesliding motion, which was favorable to the rapid dispersion of the extrusive materials and formation of extensional tectonics in the NCB (Xu et al., 1987, 1993; Ma, 1989). Additionally, thermal perturbation in response to the late Triassic collision between the Yangtze and North China Blocks had occurred during or shortly before the melting event, which resulted in potassium-rich OIB-like melt metasomatism and formation of disseminated phlogopite in mantle peridotites (Guo et al., 2001). Introduction of melt and/or fluid into the overlying mantle peridotites would likely lead to the lowering of the solidus, triggering decompression melting of the enriched lithospheric mantle once the geotherm grazed the solidus of hydrous peridotite. This model is consistent with the observations that the earlier basaltic lavas had undergone a smaller melting degree whilst relatively higher melting degrees during formation of the younger mafic intrusions, as lithospheric thinning proceeded.
Undoubtedly, the widespread exposure of Mesozoic mafic rocks with EM1-like $\mathrm{Sr}$ and $\mathrm{Nd}$ isotopic features within the NCB suggests the existence of aged and enriched lithospheric mantle beneath the NCB, mainly inherited from an Archean lithospheric keel. Based on the geochemical and isotopic characteristics of the early Tertiary basaltic lavas in the rifts around Bohai Bay, many workers have proposed that the enriched mantle still played an important role in basaltic genesis and that some volume of Archean lithospheric mantle might be still resided beneath the NCB during the Cenozoic time (Xu et al., 1995; Chen et al., 1992; Song and Frey, 1989). Further evidence from Cenozoic basalt-born mantle xenoliths adjacent to the TaihanshanDaxing' anling gravity zone indicates that the relict refractory mantle of Archean keel remains beneath the eastern NCB, where limited lithospheric thinning has occurred (Zheng et al., 2001). As a consequence of the aforementioned facts, the Archean lithospheric keel beneath NCB appears to have been progressively removed through thermal-mechanic erosion by a hot convective mantle and the induced partial melting process under extensional tectonics.

\section{CONCLUSions}

Geochemical and $\mathrm{Sr}-\mathrm{Nd}$ isotopic features of late Mesozoic mafic rocks in west Shandong Province indicate their origins by melting of an aged and enriched lithospheric mantle reservoir composed of refractory peridotites with disseminated phlogopite and $\mathrm{Sr}-\mathrm{Nd}$ isotopic EM1-like features. It is completely different from that underlying the NCB in Cenozoic time, and also shows some geochemical and isotopic differences with veined phlogopite peridotites prevalent in the early Paleozoic that might represent the lowermost part of the Archean lithosphere as a result of long-term and extensive fluid/melt-wall peridotite reaction.

The widespread exposure of late Mesozoic basaltic rocks in the interior of NCB also tends to imply that the Archean lithospheric mantle was predominant at least before the early Cretaceous, and acted as the mantle sources for the extensive 
melting event. We thus conclude that the predominance of the lost lithospheric mantle was characterized by an enriched mantle reservoir, which was progressively digested through decompressional melting process and thermo-chemical erosion by a hot convecting mantle. Taking into consideration the tectonic evolution of the blocks surrounding the NCB, the lithospheric thinning event was probably induced by lateral escape in response to NE- and S-trending indentors respectively from Indo-Sinian Block and Siberia Craton, incorporated with thermal perturbation related to the late Triassic collision between the Yangtze Block and NCB.

Acknowledgments-The authors would like to appreciate Dr. J. Yang for his assistance in performing the ICP-MS and Sr-Nd isotope analyses. Constructive reviews by two anonymous referees have greatly improved the manuscript. Prof. R. J. Arculus is acknowledged for his helpful suggestions and grammatical improvement. This study is financially supported by National Ministry of Sciences and Technology of China (No. G1999043202, G1999075504) and Chinese Academy of Sciences (No. KZCX1-107).

\section{REFERENCES}

Bedini, R. M., Bodinier, J.-L., Dautria, J.-M. and Morten, L. (1997) Evolution of LILE-enriched melt fraction in the lithospheric mantle: A case study from the East African Rift. Earth Planet. Sci. Lett. 153, 67-83.

Boyd, F. R. (1989) Composition and distinction between oceanic and cratonic lithosphere. Earth Planet. Sci. Lett. 96, 15-26.

Carlson, R. W. and Irving, A. J. (1994) Depletion and enrichment history of subcontinental lithospheric mantle: an $\mathrm{Os}, \mathrm{Sr}, \mathrm{Nd}$ and $\mathrm{Pb}$ isotopic study of ultramafic xenoliths from the northwestern Wyoming Craton. Earth Planet. Sci. Lett. 126, 457-472.

Chen, W. J., Li, D. M., Li, Q., Shen, S. W., Liang, H. D., Zhou, X. H., Liu, R. X., Wang, X., Liu, X. T. and Zheng, J. W. (1992) The age and geochemistry of basin basalts at Xialiaohe rift. The Age and Geochemistry of Cenozoic Volcanic Rocks in China (Liu, R., ed.), 44-80, The Seismological Press, Beijing (in Chinese).
Chi, J. S. and Lu, F. X. (1996) The Kimberlites and Nature of Paleozoic Lithospheric Mantle in North China Platform, 260-264, Chinese Science Press, Beijing (in Chinese).

Chi, X. G., Xu, W. L., Lin, J. Q. and Tan, D. J. (1994) $\mathrm{Nd}$ and $\mathrm{Sr}$ isotopic evidence for the petrogenesis of Mesozoic dioritic intrusives in eastern North China Platform. Mesozoic Potassic Magmatic Regions in the North China Platform (Lin, J. Q. and Tan, D. J., eds.), 66-74, The Seismological Press, Beijing (in Chinese).

Dalton, J. A. and Presnall, D. C. (1998) The continuum of primary carbonatitic-kimberlitic melt compositions in equilibrium with lherzolite: data from the system $\mathrm{CaO}-\mathrm{MgO}-\mathrm{Al}_{2} \mathrm{O}_{3}-\mathrm{SiO}_{2}-\mathrm{CO}_{2}$ at $6 \mathrm{GPa}$. J. Petrol. 39, 1953-1964.

De Smet, J. H., van den Berg, A. P. and Vlaar, N. J. (1999) The evolution of continental roots in numerical thermo-chemical mantle convection models including differentiation by partial melting. Lithos $\mathbf{4 8}$, 153-170.

Dupuy, C., Liotard, J.-M. and Dostal, J. (1992). Zr/Hf fractionation in intraplate basaltic rocks: carbonate metasomatism in the mantle source. Geochim. Cosmochim. Acta 56, 2417-2423.

Engebretson, D. C., Cox, A. and Gordon, R. G. (1985) Relative motions between oceanic and continental plates in the Pacific basins. Geological Society of America Special Paper 206, 1-59.

Fan, W. M. and Menzies, M. A. (1992) Destruction of aged lower lithosphere and accretion of asthenosphere mantle beneath eastern China. Geotectonica et Metallogenia 16, 171-180.

Fan, W. M., Zhang, H. F., Baker, J., Jarvis, K. E., Mason, P. R. D. and Menzies, M. A. (2000) On-craton and off-craton Cenozoic spinel peridotites in eastern China: Similarity and difference. J. Petrol. 41, 933950.

Foley, S. F. (1992) Vein-plus-wall-rock melting mechanism in the lithosphere and the origin of potassic alkaline magmas. Lithos 28, 435-453.

Foley, S. F., Jackson, S. E., Fryer, J. D. and Greenough, G. A. J. (1996) Trace element partition coefficients for clinopyroxene and phlogopite in an alkaline lamprophyre from Newfoundland by LAM-ICP-MS. Geochim. Cosmochim. Acta 60, 629-638.

Furman, T. (1995) Melting of metasomatized subcontinental lithosphere: undersaturated mafic lavas from Rungwe, Tanzania. Contrib. Mineral. Petrol. 122, 97-115.

Gao, S., Luo, T. C., Zhang, B. R., Kern, H. and Zhao, Z. D. (1998) Chemical composition of the continental crust as revealed by studies in East China. Geochim. Cosmochim. Acta 62, 1959-1975. 
Griffin, W. L., O'Reilly, S. Y. and Ryan C. J. (1992) Composition and thermal structure of the lithosphere beneath South Africa, Siberia and China: proton microprobe studies. Inter. Symp. on Cenozoic Volcanic Rocks and Deep-Seated Xenoliths in China and Its Environs, Beijing, 65-66.

Griffin, W. L., Zhang, A. D., O'Reilly, S. Y. and Ryan, C. J. (1998) Phanerozoic evolution of the lithosphere beneath the Sino-Korean Craton. Mantle Dynamics and Plate Interactions in East Asia (Flower, M. F. J., Chung, S. L., Lo, C. H. and Lee, T. Y., eds.), Am. Geophys. Union Geodyn. Ser. 27, 107-126.

Griffin, W. L., Doyle, B. J., Ryan, C. G., Pearson, N. J., O’Reilly, S. Y., Davies, R., Kivi, K., Van Achterbergh, E. and Natapov, L. M. (1999) Layered mantle lithosphere in the Lac de Gras area, Slave Craton: composition, structure and origin. J. Petrol. 40, 705-728.

Guo, F., Fan, W. M., Wang, Y. J. and Lin, G. (2001) Late Mesozoic mafic intrusive complexes in the North China Block: Constrains on the nature of subcontinental lithospheric mantle. Phys. Chem. Earth 26, 759-771.

Hacker, B. R., Ratschbacher, L., Webb, L., McWilliams, M. O., Ireland, T., Calvert, A., Dong, S. W., Wenk, H. R. and Chateigner, D. (2000) Exhumation of ultrahigh-pressure continental crust in east central China: Late Triassic-early Jurassic tectonic unroofing. J. Geophys. Res. 105(B6), 13339-13364.

Hart, S. R. (1988) Heterogeneous mantle domains: signature, genesis and mixing chronologies. Earth Planet. Sci. Lett. 90, 273-296.

Ionov, D. A, O’Reilly, S. Y. and Griffin W. L. (1997) Volatile-bearing minerals and lithophile trace elements in the upper mantle. Chem. Geol. 141, 153184.

Kennedy, A. K., Lofgren, G. E. and Wasserburg, G. J. (1993) An experimental study of trace element partition between olivine, orthopyroxene and melt in chondrules: Equilibrium values and kinetic effects. Earth Planet. Sci. Lett. 115, 177-195.

Lin, J. Q., Tan, D. J. and Jin, Y. (1996) ${ }^{40} \mathrm{Ar} /{ }^{39} \mathrm{Ar}$ ages of Mesozoic igneous rocks from west Shandong Province, China. Acta Petrologica et Mineralogica 15, 213-220 (in Chinese with English abstract).

Liu, D. Y., Nutman, A. P., Compston W., Wu, J. S. and Shen, Q. H. (1992) Remnants of 3800 Ma crust in the Chinese part of the Sino-Korean craton. Geology 20, 339-342.

Ma, X. Y. (1989) Atlas of Active Faults in China. Beijing Seismological Press, Beijing, 20-125 pp. (in Chinese).

McKenzie, D. P. and Bickle, M. J. (1988) The volume and composition of melt generated by extension of the lithosphere. J. Petrol. 32, 625-679.

Menzies, M. A. (1989) Cratonic, circum-cratonic and oceanic mantle domains beneath the western U.S.A. J. Geophys. Res. 94, 7899-7915.

Menzies, M. A., Fan, W. M. and Zhang, M. (1993) Paleozoic and Cenozoic lithoprobes and loss of $>120$ km of Archaean lithosphere, Sino-Korean Craton, China. Magmatic Processes and Plate Tectonics (Pichard, H. M., Alabaster, T., Harris, N. B. W. et al., eds.), Geol. Soc. Spec. Pub. 76, 71-78.

Pearson, D. G., Shirey, S. B., Carlson, R. W., Boyd, F. R., Pokhilenko, N. P. and Shimizu, N. (1995) Re-Os, $\mathrm{Sm}-\mathrm{Nd}$ and $\mathrm{Rb}-\mathrm{Sr}$ isotope evidence for thick Archean lithospheric mantle beneath the Siberian craton modified by multi-stage metasomatism. Geochim. Cosmochim. Acta 59, 959-977.

Ratschbacher, L., Hacker, B. R., Webb, L., McWilliams, M. O., Ireland, T., Calvert, A., Dong, S. W., Chateigner, D. and Wenk, H. R. (2000) Exhumation of ultrahigh-pressure continental crust in east central China: Cretaceous and Cenozoic unroofing and Tan-Lu fault. J. Geophys. Res. 105(B6), 1330313338.

Regional Geological Survey of Shandong Province (1991) Geology of Shandong Province. Beijing Geological Press, Beijing, 572 pp. (in Chinese).

Schmidt, K. H., Bottazzi, P., Vannucci, R. and Mengel, K. (1999) Trace element partitioning between phlogopite, clinopyroxene and leucite lamproite melt. Earth Planet. Sci. Lett. 168, 287-299.

Shao, J. A., Li, X. H., Zhang, N. Q. and Mou, B. L. (2001) Petrogenesis of Mesozoic bimodal intrusive dikes at Nankou-Guyaju area in the Yanshanian Orogen, northern North China Block: Sr-Nd isotopic constraints. Geochimica 30, 517-524 (in Chinese with English abstract).

Song, Y. and Frey, R. F. (1989) Geochemistry of peridotite xenoliths in basalt from Hannuoba, eastern China: Implications for subcontinental mantle heterogeneity. Geochim. Cosmochim. Acta 53, 97113

Sun, S. S. and McDonough, W. F. (1989) Chemical and isotopic systematics of oceanic basalts: implication for mantle composition and processes. Magmatism in the Ocean Basins (Saunder, A. D. and Norry, M. J., eds.), Geol. Soc. Spec. Pub. 42, 313-345.

Tan, D. J. and Lin, J. Q. (1994) The Mesozoic Potassic Magma zones in North China Platform. The Seismological Press, Beijing, 27 pp. (in Chinese).

Taylor, S. R. and McLennan, S. M. (1985) The Continental Crust: Its Composition and Evolution. Oxford Press, Blackwell, 312 pp.

Walker, R. J., Carlson, R. W. and Shirey, S. B. (1989) $\mathrm{Os}, \mathrm{Sr}, \mathrm{Nd}$ and $\mathrm{Pb}$ isotope systematics of southern 
African peridotite xenoliths: Implications for the chemical evolution of subcontinental mantle. Geochim. Cosmochim. Acta 53, 1583-1595.

Wang, W. Y., Takahashi, E. and Sueno, S. (1998) Geochemical properties of lithospheric mantle beneath the Sino-Korean craton: evidence from garnet xenocrysts and diamond inclusions. Phys. Earth Planet. Inter. 107, 249-260.

Xu, J., Ma, G., Zhu, G., Tong, W. X., Gui, K. R. and Liu, Q. (1987) Formation and evolution of the Tancheng-Lujiang wrench fault system: a major shear system to the northwest of the Pacific Ocean. Tectonophysics 134, 273-310.

Xu, J., Ma, G., Tong, X., Zhu, G. and Lin, S. (1993) Displacement of Tancheng-Lujiang wrench fault system and its geodynamic setting in the northwestern Circum-Pacific. The Tancheng-Lujiang Wrench System (Xu, J., ed.), 51-74, John Wiley \& Sons.

Xu, X., O'Reilly, Y. S., Griffin, W. L. and Zhou, X. (2000) Genesis of young lithospheric mantle in southeastern China: A LAM-ICP-MS trace element study. J. Petrol. 41, 111-148.

Xu, Y. G., Fan, W. M. and Lin, G. (1995) Lithosphereasthenosphere interaction: A comparative study on
Cenozoic and Mesozoic basalts around Bohai Area. Geotectonica et Metallogenia 19, 1-13.

Yaxley, G. M., Crawford, A. J. and Green, D. H. (1991) Evidence for carbonatite metasomatism in spinel peridotite xenoliths from Western Victoria. Earth Planet. Sci. Lett. 107, 305-317.

Yuan, X. C. (1996) Altas of geophysics in China. Geophysical Map Collections in China (Yuan, X. C., ed.), 59-62, Geological Press, Beijing (in Chinese).

Zheng, J. P. (1999) Mesozoic-Cenozoic Mantle Replacement and Lithospheric Thinning Beneath the Eastern China. China University of Geoscience Press, Wuhan, 125 pp. (in Chinese).

Zheng, J. P., O’Reilly, S. Y., Griffin, W. L., Lu, F. X., Zhang, M. and Pearson, N. J. (2001) Relict refractory mantle beneath the eastern North China Block: significance for lithospheric evolution. Lithos 57, 4366.

Zhou, X. H., Zhang, G. H., Yang, J. H., Chen, W. J. and Sun, M. (2001) Sr-Nd-Pb isotope mapping of late Mesozoic rocks across northern margin of North China Block and implications to geodynamic processes. Geochimica 30, 10-23 (in Chinese with English abstract). 